\title{
Effects of crossbreeding on carcass and meat quality of Mexican lambs
}

[Efeito do cruzamento sobre o rendimento de carcaça e a qualidade da carne de cordeiros mexicanos]

\author{
L. Hernández-Cruz ${ }^{1}$, J.E. Ramírez-Bribiesca ${ }^{1 *}$, M.I. Guerrero-Legarreta ${ }^{2}$, O. Hernández-Mendo ${ }^{1}$, \\ M.M. Crosby-Galvan ${ }^{1}$, L.M. Hernández-Calva ${ }^{3}$ \\ ${ }^{1}$ Colegio de Posgraduados - Instituto de Recursos Genéticos y Productividad-Ganadería \\ C.P. 56230 - Montecillo, Texcoco, México \\ ${ }^{2}$ Departamento de Biotecnología - Universidad Autónoma Metropolitana-Unidad Iztapalapa \\ ${ }^{3}$ Facultad de Medicina Veterinaria y Zootecnia - Universidad Autónoma de Tlaxcala
}

\begin{abstract}
Twenty hair (Pelibuey x Katadin x BlackBelly) and 20 wool (Rambouillet x Criollo) lambs were fattened in an intensive feeding system to reach $40 \mathrm{~kg}$ body weight at ten months of age. The yield of lamb sides and back fat $(51.9 \%, 2.5 \mathrm{~mm}$ vs. $47.0 \%, 2.3 \mathrm{~mm})$ were greater in wool lambs. Meat $\mathrm{pH}$ was not different between phenotypes but meat temperature was higher during the first hours postmortem in wool lamb sides $(27,23$, and 20, vs. 24, 20 , and $17^{\circ} \mathrm{C}$ ). Protein content in meat from the neck (braquicephalic and esternocephalic muscles) and loin (Longissimus lumborum muscle) were higher in hair lambs (21.1 and 20.4 vs. 19.7 and 19.3\%), while moisture of the same muscles was higher in wool lambs (75.6 and 75.9 vs. 73.6 and $74.3 \%)$. Ash content was similar in both phenotypes, but palmitoleic acid was greater in hair lambs (2.9 and 2.7 vs. 2.7 and 2.5\%). In fresh meat, $\mathrm{pH}$, meat toughness, and water activity (Wa) of loin did not differ; but water holding capacity (WHC) was higher in hair lambs, and the same response was observed for cooked meat toughness from the neck, and in raw and cooked meat from loin. There were differences in the colour of meat from the neck, having values for $\mathrm{L}^{*}$, $\mathrm{b}^{*}$ and tonalities greater in wool lambs, and $\mathrm{a}^{*}$ greater for hair lambs. Sensorial parameters were similar in both phenotypes.
\end{abstract}

Keywords: lamb meat, physicochemical characteristics, fatty acids, sensorial test

\section{RESUMO}

Vinte cordeiros deslanados (Pelibuey x Katadin x BlackBelly) e 20 cordeiros lanados (Rambouillet $x$ Criollo) foram mantidos em um sistema intensivo de alimentação até atingirem 40kg, aos 10 meses de idade. $O$ rendimento de carcaça e a espessura da gordura foram maiores nos cordeiros lanados (51,9\%, 2,5mm vs. $47,0 \%, 2,3 \mathrm{~mm}$ ). Não houve diferenças entre os dois grupos de cordeiros para $\mathrm{pH}$, mas a temperatura da carne foi mais alta durante as primeiras horas pós-morte, nas meias-carcaças dos cordeiros lanados (27, 23, 20 vs. $24,20,17^{\circ} \mathrm{C}$ ). O conteúdo proteico da carne do pescoço (músculos braquicefálico e esternocefálico) e do lombo (músculo Longissimus lumborum) foi maior nos cordeiros deslanados (21,1 e 20,4 vs. 19,7 e 19,3\%) enquanto o teor de umidade foi maior nas lanados (75,6 e 75,9 vs 73,6 e 74,3\%). O conteúdo de cinzas não diferiu entre os dois grupos de cordeiros, mas o ácido palmitoleico foi maior nos cordeiros deslanados (2,9e 2,7 vs 2,7 e 2,5\%). Na carne fresca, o pH, a maciez da carne e a atividade da água (Wa) do lombo não diferiram entre os grupos, mas a capacidade de retenção de água (WHc) foi maior nos cordeiros deslanados, $e$ a mesma resposta foi observada para a maciez da carne cozida do pescoço e do lombo fresco e cozido. Houve diferenças para cor da carne do pescoço com valores de $L^{*}, b^{*}$ e maior tonalidade entre os cordeiros lanados, e maior $a^{*}$ para os deslanados. Os parâmetros sensoriais foram semelhantes nos dois grupos.

Palavras-chave: cordeiro, carne, características físicoquímicas, ácidos graxos, teste sensorial

\section{INTRODUCTION}

In Mexico, there has been high interest in quality of lamb meat. The fact that the carcass and meat qualities of hair and wool lambs produced in this country are diverse and the dearth of information particularly from the plateau region where consumers prefer meat from wool or hair lambs. A previous study has shown that the Pelibuey breed

Recebido em 29 de dezembro de 2008

Aceito em 10 de março de 2009

*Autor para correspondência (corresponding author)

E-mail: efrenrb@colpos.mx 
has a lower carcass yield when compared to other breeds (Cantón and Velázquez, 1993). But, the economic viability of wool production is limited by the low wool price and sheep farmers are increasingly forced to wool sheep part of their herds with meat-producing. However, hair and wool sheep productions have increased dramatically in recent years. This is partly due to the potential for accelerated meat production, since most hair sheep have extended breeding season and high fertility. Hair sheep in Mexico originated from the Pelibuey, Katadin, and Blackbelly, while wool sheep is originated from Rambouillet and Criollo. Both crossbreds are native sheep in Mexican plateau and they have many advantages for small farm flock production. Lambs have traditionally been finished in feedlots with high-energy diets and they have been shown to improve growth rates in different sheep breeds.

Limited research has been done on the effect of breed and the meat quality of lambs, especially with regard to the sensorial characteristics. One of the main reasons is that some local consumers reject lamb hair meat or lamb wool meat due to the characteristic flavor, but this habit does not have a scientific support and it is exclusive in each or different regions of Mexico. These lambs are traditionally consumed as barbacoa, a traditional dish which reduces lamb meat quality attributes. But, at present, there is an emerging business to sell cuts of lamb for specific market demands. In order to satisfy newer high standards in the meat market, it is imperative to evaluate meat quality, and the differences in quality among breeds or crossbreds, and feeding systems to judge processes producing higher quality meat. Such research would provide insights into those processes that best meet market demands and thus increase producer profits.

Although consumer preferences for meat are difficult to define, the most important quality features in meat are sensorial characteristics. Previous studies suggest that the fatty acid composition of lamb can be influenced by diet, with consequences for other important quality attributes, most notably flavor which is a major determinant in eating satisfaction. There is anecdotal, but little scientific, evidence that the meat from lambs of certain breeds reared on particular diet has unique or characteristic flavor.

Recently, a series of optional norms to classify sides of lamb was produced in Mexico, included were meat quality criteria that producers, wholesale dealers, and butchers appreciate. Yet, such criteria are often subjective and ignored such as fat content and marbling, hardness, odour, succulence, juiciness, and color. Further, there are differences among lambs grown for meat or wool and fed on high grain diets; such as meat yield and hardness. Very little is known on carcass and meat quality of hair and wool sheep raised using locally available feed resources in feedlot system. Therefore, the objective of this study was to evaluate physicochemical and sensorial (taste, odor, and texture) characteristics of meat from hair and wool lambs fed on a high grain diet.

\section{MATERIAL AND METHODS}

Carcasses from forty intact male lambs were distributed into two groups: 20 hair lambs and 20 wool lambs. All lambs came from native sheep located on the Mexican plateau obtained of different breeds and classified as hair lambs (Pelibuey x Katadin and Blackbelly) and wool lambs (Rambouillet x Criollo). All lambs were raised on intensive feeding systems with a high cereal diet containing $2.8 \mathrm{Mcal} / \mathrm{kg}$ dry matter and $16 \%$ total protein and weighed $40 \mathrm{~kg}$ at ten-month old.

Prior to slaughtering, the lambs were subjected to a $12 \mathrm{~h}$ fasting period. After slaughtering, all body components such as head, limbs (separated at metatarsal and metacarpal joints), skin, blood, gastrointestinal full and empty were weighed and classified in terms of their respective percentages with respect to the live weight (LW) of the animal. Empty body weight (EBW) was calculated by deducting the weight of stomach contents from fasted liveweight at slaughtering. Hot carcass weight (HCW) was recorded and it included kidneys and testicles weights according to the Mexican norm for carcass evaluation (Norma..., 2006). Warm carcasses were refrigerated in a cooled room maintained at $4^{\circ} \mathrm{C}$. The following day, the cold carcass weight $(\mathrm{CCW})$, commercial and biological dressing percentages were calculated according to the following formulae:

- Commercial dressing percentage $=\mathrm{HCW} / \mathrm{LW} \times 100$

- Biological dressing percentage $=\mathrm{CCW} / \mathrm{EBW} \times 100$

Meat $\mathrm{pH}$ and temperature were assessed by placing a potenciometric probe $^{1}$ inside the Longissimus lumborum muscle every hour for six hours, and other measure at $24 \mathrm{~h}$ after slaughtering. After chilling the carcasses for 24 hours, fat depth (FD) was measured with a FD knife placed in the intercostal cavity of the $12^{\text {th }} \mathrm{rib}, 4 \mathrm{~cm}$ from the spine, as described by the Mexican norm for carcass evaluation (Norma..., 2006). Cold carcass 
were split down the transversal midline and during cut preparation, loin and neck samples were taken from the Longissimus lumborum, braquicephalic, and esternenocephalic muscles, in order to analyze: moisture, ash, protein (Official..., 2000), and fatty acids by gas chromatography ${ }^{2}$ using an automatic injector (Cañeque and Sañudo, 2000). These samples were also analyzed for water activity $(\mathrm{WA})^{3}$, water holding capacity $(\mathrm{WHC})^{3}$, and color ${ }^{3}$. Color and chromatic values were reported as $\mathrm{L}^{*}$, $a^{*}, b^{*}$, and shades $\left(\tan ^{-1} \mathrm{~b} / \mathrm{a}\right.$ angle and magnitude $\left.\left.\left(a^{2}+b^{2}\right)^{1 / 2}\right) \cdot g\right)$. Hardness raw and cooked meat were measured as resistance to cutting using a WarnerBratzler shear in a TA-XT2 texture analyzer ${ }^{4}$, at $5 \mathrm{~mm}$ test speed and $5 \mathrm{~mm} / \mathrm{s}$ backing speed, being applied $0.981 \mathrm{~N}$ force. The last variable was analyzed using cooked meat from both muscles, reporting data on the maximun force applied to cut the sample when a known force is applied (Guerrero et al., 2002). A sensorial test was performed on loin samples (Longissimus lumborum muscle). Samples were cooked under slow heat at a maximum of $70^{\circ} \mathrm{C}$ for $15 \mathrm{~min}$. Panellists were asked to rate meat hardness, juiciness, flavour intensity, and overall acceptability using a structured scale of six points for each of the sensory traits (Guerrero at al., 2002).

Results were analyzed using Student t-tests for independent means (Herrera and Barreras, 2005) at a $5 \%$ level of significance. Data analyses were performed using SPSS version 11, except for $\mathrm{pH}$ and temperature of the sides of meat which were analyzed using a mixed analysis of variance (PROC MIXED) by SAS/1999 for a completely randomized experimental design using repeated measures over time.

\section{RESULTS AND DISCUSSION}

Dressing percentages of hair lambs were higher $(\mathrm{P}>0.001 ; 51.9$ and $56.8 \%)$ than wool lambs (47 and $50.8 \%$ ) (Table 1). This occurred because wool lambs have heavier skin $(\mathrm{P}<0.05)$ and viscera $(\mathrm{P}<0.001)$ than hair lambs. Similar findings were reported by Burke et al. (2003) who found different fresh meat yield among Dorper, St. Croix, Romanov, Katadin, and the Dorper $\mathrm{x}$ Romanov $\mathrm{x}$ St. Croix cross. These results are also similar to those of Gutierrez et al. (2005) who used Pelibuey, Suffolk x Pelibuey, and Rambouillet x Pelibuey breeds.

Table 1. Body proportions and carcass characteristics of hair and wool lambs (mean \pm standard error)

\begin{tabular}{|c|c|c|c|}
\hline \multirow{2}{*}{ Variable } & \multicolumn{2}{|c|}{ Lamb phenotype } & \multirow{2}{*}{$\mathrm{P}$} \\
\hline & Hair & Wool & \\
\hline Live weight (kg) & $40.1 \pm 0.58$ & $39.3 \pm 0.52$ & NS \\
\hline Head $(\mathrm{kg})$ & $1.8 \pm 0.03$ & $1.8 \pm 0.03$ & NS \\
\hline$(\%)$ & $4.4 \pm 0.09$ & $4.7 \pm 0.08$ & NS \\
\hline Blood (kg) & $1.7 \pm 0.04$ & $1.6 \pm 0.05$ & NS \\
\hline$(\%)$ & $4.2 \pm 0.10$ & $4.1 \pm 0.12$ & NS \\
\hline Skin $(\mathrm{kg})$ & $3.6 \pm 0.09$ & $4.4 \pm 0.26$ & $*$ \\
\hline$(\%)$ & $8.9 \pm 0.19$ & $11.2 \pm 0.60$ & $* * *$ \\
\hline Limbs $(\mathrm{kg})$ & $0.9 \pm 0.02$ & $0.9 \pm 0.02$ & NS \\
\hline$(\%)$ & $2.2 \pm 0.04$ & $2.4 \pm 0.03$ & NS \\
\hline GI viscera $(\mathrm{kg})$ & $4.2 \pm 0.22$ & $3.7 \pm 0.17$ & NS \\
\hline$(\%)$ & $10.6 \pm 0.58$ & $9.3 \pm 0.37$ & NS \\
\hline Remaining viscera (kg) & $1.2 \pm 0.11$ & $2.5 \pm 0.04$ & $* * *$ \\
\hline$(\%)$ & $3.1 \pm 0.25$ & $6.3 \pm 0.10$ & *** \\
\hline GI content $(\mathrm{kg})$ & $4.4 \pm 0.23$ & $4.1 \pm 0.18$ & NS \\
\hline$(\%)$ & $10.8 \pm 0.47$ & $10.4 \pm 0.39$ & NS \\
\hline Empty body weight (kg) & $35.7 \pm 0.62$ & $35.2 \pm 0.44$ & NS \\
\hline Hot carcass weight $(\mathrm{kg})$ & $20.8 \pm 0.27$ & $18.5 \pm 0.27$ & $* * *$ \\
\hline Cold carcass weight (kg) & $20.3 \pm 0.27$ & $17.9 \pm 0.27$ & $* * *$ \\
\hline Commercial dressing $(\%)$ & $51.9 \pm 0.47$ & $47.0 \pm 0.51$ & $* * *$ \\
\hline Biological dressing (\%) & $56.8 \pm 0.87$ & $50.8 \pm 0.40$ & $* * *$ \\
\hline Fat depth $(\mathrm{mm})$ & $2.5 \pm 0.05$ & $2.3 \pm 0.04$ & * \\
\hline
\end{tabular}

\footnotetext{
${ }^{1}$ Hanna (mod. HI99163) - Mexico, Mexico.

${ }^{2}$ Hewlett Packard 6890 - Ramsey, USA.

${ }^{3}$ Hunter Lab. System, Minolta-Chromameter CR-200 colorimeter - Tokyo, Japan.

${ }^{4}$ Texture Technologies Corp. - Scarsdale, USA.
} 
Back fat cover was thicker for hair lambs than that in wool lambs. Bunch et al. (2004) found higher values in wool lambs than in the St. Croix breed (hair lambs). In this regard, Sañudo et al. (1998) stated that lambs from rustic (genetically adapted to harsh conditions) and proliferous groups such as Pelibuey tend to accumulate more fat that other specialized breeds. However, Gutierrez et al. (2005) observed greater fat accumulation in Rambouillet $x$ Pelibuey than in Pelibuey alone.

Animal phenotype did not influence $\mathrm{pH}$ of the meat ( $\mathrm{P}>0.05$; Fig. 1). Meat $\mathrm{pH}$ declined as post mortem time increased in hair (6.34 to 5.53) and wool lambs (6.24 to 5.48). This response is caused by transformation of glycogen into lactic acid (by anaerobic glycolysis), causing $\mathrm{pH}$ to decline during the first 24h (Carballo and López, 2001). After that time, there is a degradation of myofibril proteins that increase $\mathrm{pH}$ (Carballo and López 2001). Teixeira et al. (2005) compared Bragancana and Mirandesa lamb breeds and found $\mathrm{pH}$ differences as early as one hour postmortem, but they did not find differences at $24 \mathrm{~h}$ after. Similarly, Martinez-Cerezo et al. (2005a) reported differences between Aragonesa, Churra, and Merino breeds. Meat temperature of the sides was different $(\mathrm{P}<0.01)$ between phenotypes during the first $3 \mathrm{~h}$ post-mortem; sides from hair lambs had a lower temperature than sides from wool lambs, and no differences were observed between four to six hours. Twenty-four hours after slaughter, meat sides from hair lambs had a higher temperature than meat from wool lambs (Fig. 2). Overall, temperature decreased over time after slaughtering.

Table 2 shows meat chemical composition. Meat moisture from the loins of wool lambs was $2.12 \%$ greater $(\mathrm{P}<0.05)$ that that for hair lambs, while protein content was $5.05 \%$ higher $(\mathrm{P}<0.001)$ in hair than wool lambs. The same response for both variables was observed on meat from neck muscles. Meat moisture was $2.63 \%$ higher $(\mathrm{P}<0.05)$ in wool than hair lambs, while protein content was $6.76 \%$ greater $(\mathrm{P}<0.05)$ from hair lambs. Results also indicate a similar $(\mathrm{P}>0.05)$ ash content of meat from both loin and neck in both phenotypes. Apparently, ash content is constant in breeds and differences among breeds are uncommon. For example, Hoffman et al. (2003) found no differences in this variable among Dorper, Suffolk, Merino, and Dohne Merino breeds, but they do report differences in protein content among them.

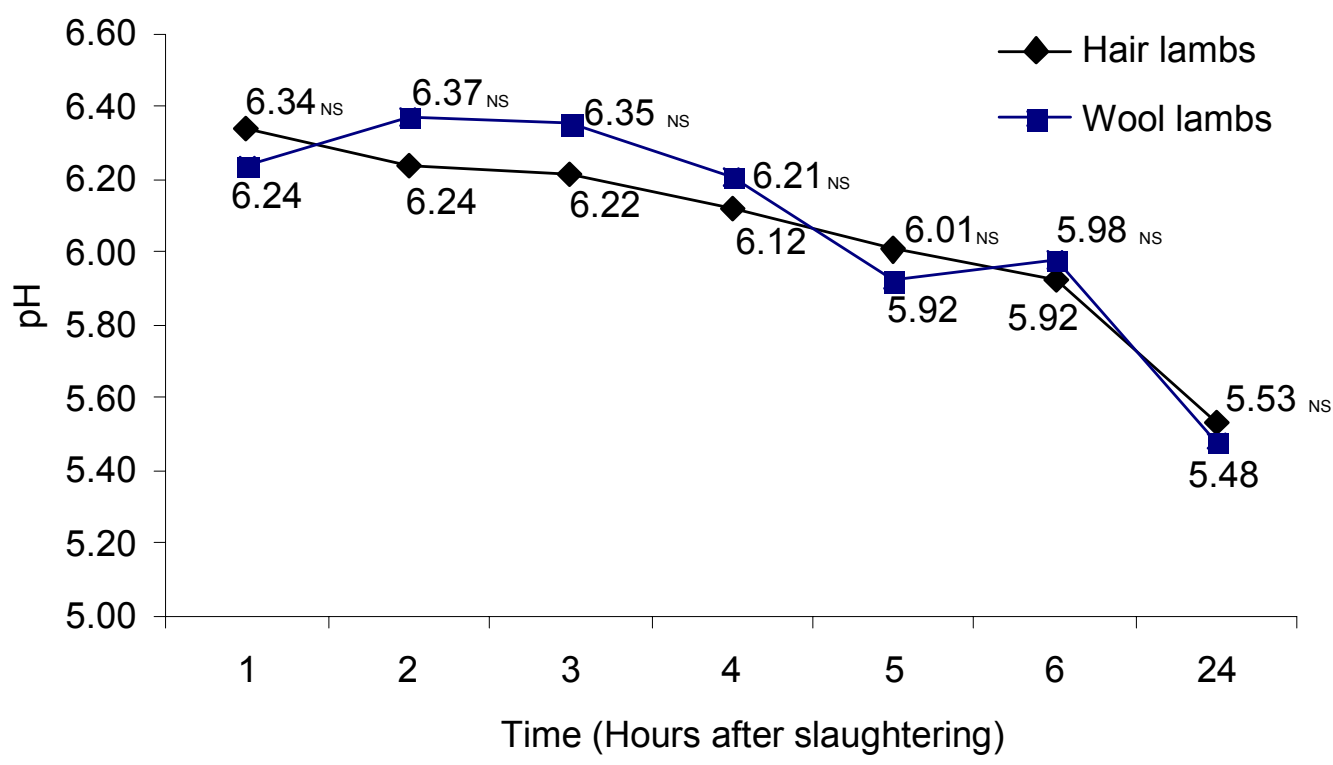

Figure 1. Meat $\mathrm{pH}$ of sides from wool and hair lambs at different hours after slaughtering. $* \mathrm{P} \leq 0.05 ; * * \mathrm{P} \leq 0.01 ; * * * \mathrm{P} \leq 0.001 ; \mathrm{NS} \mathrm{P}>0.05$. 


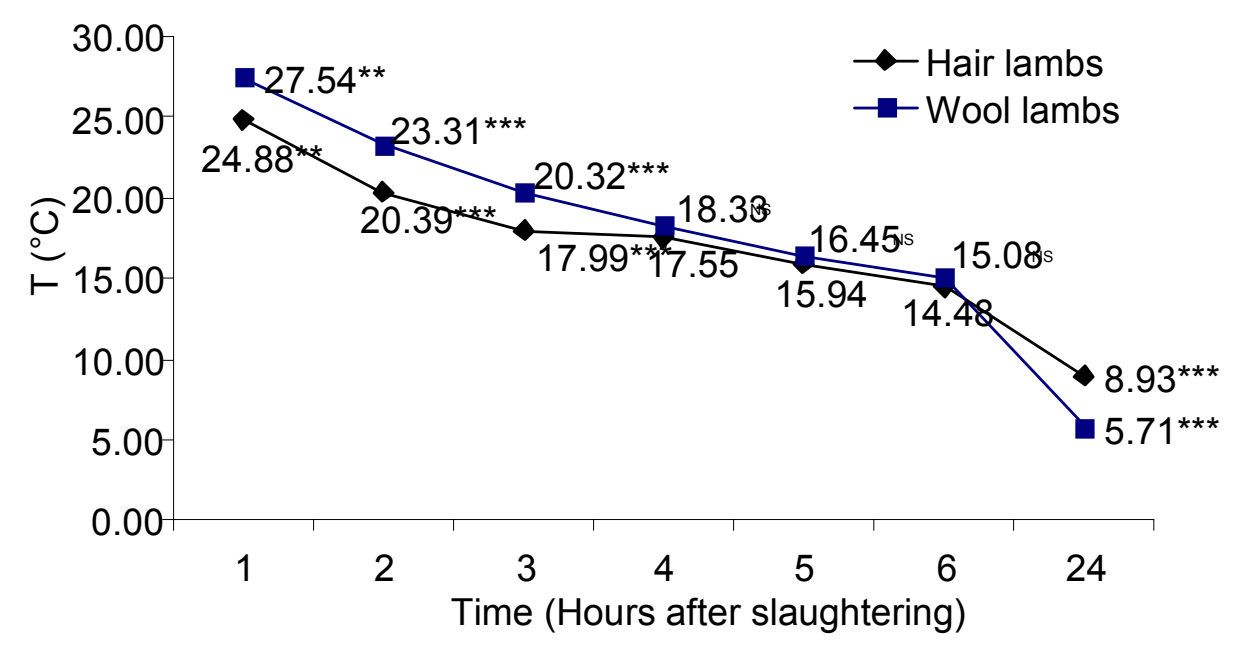

Figure 2. Meat temperature of sides from wool and hair lambs at different hours after slaughtering. * $\mathrm{P} \leq 0.05 ; * * \mathrm{P} \leq 0.01 ; * * * \mathrm{P} \leq 0.001 ; \mathrm{NS} \mathrm{P}>0.05$.

Table 2. Effect of phenotype and body part on the chemical composition of lamb meat (mean \pm standard error)

\begin{tabular}{|c|c|c|c|}
\hline \multirow{2}{*}{ Variable } & \multicolumn{2}{|c|}{ Lamb phenotype } & \multirow{2}{*}{$\mathrm{P}$} \\
\hline & Hair & Wool & \\
\hline \multicolumn{4}{|l|}{ Neck } \\
\hline Moisture (\%) & $73.6 \pm 0.83$ & $75.6 \pm 0.48$ & $*$ \\
\hline Protein $(\%)$ & $21.1 \pm 0.53$ & $19.7 \pm 0.30$ & $*$ \\
\hline Ash $(\%)$ & $0.8 \pm 0.05$ & $0.9 \pm 0.04$ & NS \\
\hline \multicolumn{4}{|l|}{ Loin } \\
\hline Moisture (\%) & $74.3 \pm 0.21$ & $75.9 \pm 0.69$ & $*$ \\
\hline Protein $(\%)$ & $20.4 \pm 0.18$ & $19.3 \pm 0.19$ & $* * *$ \\
\hline Ash (\%) & $0.8 \pm 0.04$ & $0.8 \pm 0.03$ & NS \\
\hline
\end{tabular}

* $\mathrm{P} \leq 0.05 ; * * \mathrm{P} \leq 0.01 ; * * * \mathrm{P} \leq 0.001 ; \mathrm{NS} \mathrm{P}>0.05$.

Content of long-chain fatty acids are shown in Table 3. Of all the fatty acids studied, only palmitoleic acid content differed $(\mathrm{P}<0.05)$ between hair and wool lambs by having a higher concentration in the former for both neck $(8.9 \%)$ and loin $(8.5 \%)$ (Table 3$)$. Other researchers have used different muscle groups and received the same results. For example, Salvatori et al. (2004) reported that concentrations of palmitoleic acid in the semimembranosus muscle of lambs differed between the crosses French Ile $x$ Pagliarola and Gentile di Puglia $x$ Sopravissana. However, the same authors reported no differences in the Longissimus lumborum and gluteobiceps muscles. Arsenos et al. (2006), on the other hand, observed different concentrations of palmitic fatty acid among Boutsco, Serres, and Karagounico lamb breeds. The present study reveals the most abundant fatty acids in the neck and loin of hair and wool lambs, as being oleic, stearic, and palmitic acids. These results agree with those reported by Hoffman et al. (2003) for the semimembranosus muscles in different breeds of lambs. Further, Sañudo et al. (2000) reported high concentrations of the same acids in the breeds Aragonesa, Merino, Montaña Galesa, and Cordero Temprano. Diaz et al. (2005) observed differences in the concentrations of oleic, stearic, and palmitic acids in meat from Spain, Germany, Uruguay, and the United Kingdom. 
Table 3. Effect of phenotype and body part on long chain fatty acids in lamb meat (mean \pm standard error)

\begin{tabular}{|c|c|c|c|c|c|}
\hline \multirow{2}{*}{ Fatty Acid (\%) } & \multicolumn{4}{|c|}{ Phenotype } & \multirow{2}{*}{$\mathrm{P}$} \\
\hline & \multicolumn{2}{|r|}{ Hair } & \multicolumn{2}{|c|}{ Wool } & \\
\hline \multicolumn{6}{|l|}{ Neck } \\
\hline Miristic (14:0) & 2.2 & 0.06 & 2.2 & 0.09 & NS \\
\hline Palmitic (16:0) & 25.2 & \pm 0.35 & 25.5 & \pm 0.33 & NS \\
\hline Palmitoleic (16:1) & 2.9 & \pm 0.10 & 2.7 & \pm 0.08 & $*$ \\
\hline Estearic $(18: 0)$ & 16.7 & \pm 0.38 & 17.8 & \pm 0.54 & NS \\
\hline Oleic $(18: 1)$ & 43.8 & \pm 0.48 & 43.4 & \pm 0.47 & NS \\
\hline Linoleic (18:2) & 8.7 & \pm 0.32 & 8.1 & \pm 0.33 & NS \\
\hline Linolenic (18:3) & 0.5 & 0.16 & 0.3 & \pm 0.15 & NS \\
\hline \multicolumn{6}{|l|}{ Loin } \\
\hline Miristic (14:0) & 2.1 & 0.08 & 1.9 & \pm 0.09 & NS \\
\hline Palmitic (16:0) & 24.7 & \pm 0.47 & 24.4 & \pm 0.32 & NS \\
\hline Palmitoleic (16:1) & 2.7 & 0.08 & 2.5 & \pm 0.06 & $*$ \\
\hline Estearic $(18: 0)$ & 16.1 & \pm 0.23 & 16.6 & \pm 0.37 & NS \\
\hline Oleic $(18: 1)$ & 42.8 & 0.61 & 43.3 & 0.48 & NS \\
\hline Linoleic (18:2) & 10.53 & \pm 0.37 & 10.00 & 0.47 & NS \\
\hline Linolenic (18:3) & 1.10 & 0.20 & 1.22 & 0.30 & NS \\
\hline
\end{tabular}

* $\mathrm{P} \leq 0.05$; ** $\mathrm{P} \leq 0.01 ;{ }^{* *} \mathrm{P} \leq 0.001 ; \mathrm{NS} \mathrm{P}>0.05$.

Table 4 presents the physicochemical characteristics of the meat from both hair and wool lambs. While the $\mathrm{pH}$ of neck meat was not different between the two phenotypes, significant differences $(\mathrm{P}<0.001)$ existed for loin (Table 4). The observed values of $\mathrm{pH}$ were in the normal range for meat (5.8 to 6.2), and indicate that the lambs did not suffer from significant stress at the time of sacrifice (Felix et al., 2001). Hopkins and Forgaty (1998) did not observe differences in $\mathrm{pH}$ among four muscles from different breeds of lambs. Tschirhart-Hoelscher et al. (2006) compared 18 different muscles from wool lambs and observed differences among the Longissimus thoracis, Longissimus lumborum, and semimembranosus muscles, with an average $\mathrm{pH}$ of 5.9. This result is important because of the relationship between $\mathrm{pH}$ and CRA (Huff-Lonergan and Lonergan, 2005). The values recorded by the present study of WHC were significantly different in neck $(\mathrm{P}<0.001)$ and loin $(\mathrm{P}<0.05)$ with higher values in hair lambs, suggesting that meat retained more liquid in its interior; a benefit for cooking. Water activity also was slightly higher for hair lambs $(\mathrm{P}<0.05)$, indicating more water availability to enhance microorganism development in the meat. It is important to highlight that the observed water activity $(0.98-0.99)$ was below the threshold considered normal for meats (Ranken, 2003).

The toughness of raw meat from the neck did not differ between breeds $(\mathrm{P}>0.05)$, but toughness of cooked meat from the neck did differ significantly $(\mathrm{P}<0.05)$. Raw $(\mathrm{P}<0.001)$ and cooked meat from the loin $(\mathrm{P}<0.001)$ were better in wool lambs, with their lower values indicating the meat was more tender, and less force was needed to cut it. MartinezCerezo et al. (2005b) observed differences among the Spanish breeds Aragonesa, Churra, and Merino, but found no differences between muscles within the same breeds. Hopkins and Fogarty (1998) observed no differences in the toughness of cooked meat, while Huidobro et al. (2005) reported more force was needed to cut cooked than raw meat, which disagrees with the findings of the present study.

Table 5 shows the results of meat color. $\mathrm{L}^{*}$ of meat from the neck differed between hair and wool lambs $(\mathrm{P}<0.001)$, being higher for wool lambs, indicating that meat was lighter in color (Hunt et al., 1991) (Table 5). Values for $a^{*}$ also differed between breeds $(\mathrm{P}<0.01)$, and higher values for hair lambs indicated more red meat in this phenotype. For $\mathrm{b}^{*}$, values were greater $(\mathrm{P}<0.05)$ in meat of wool lambs, indicating an increased yellow color. Meat tonality was greater $(\mathrm{P}<0.001)$ in hair lambs. Alcalde and Negueruela (2001) observed differences in $\mathrm{L}^{*}, \mathrm{a}^{*}$, and $\mathrm{b}^{*}$ in the triceps, braquialis, and Longissimus lumborum muscles between a number of breeds, and Martinez-Cerezo et al. (2005b) observed differences in $\mathrm{L}^{*}, \mathrm{a}^{*}$, and $\mathrm{b}^{*}$ in meat from three Spanish breeds. In the present study, loin meat from hair and wool lambs were not significantly different $(\mathrm{P}>0.05)$ for $\mathrm{L}^{*}, \mathrm{a}^{*}, \mathrm{~b}^{*}$, tonality, or chromaticity. Burke et al. (2003) compared Dorper, St. Croix, Romanov, Katahdin, and Dorper $x$ Romanov x St. Croix and observed differences in $\mathrm{a}^{*}, \mathrm{~b}^{*}$, and tonality, but not in $\mathrm{L}^{*}$. 
Effects of crossbreeding on carcass...

Table 4. Effect of phenotype and body part in the physicochemical characteristics of lamb (mean \pm standard error)

\begin{tabular}{|c|c|c|c|}
\hline \multirow{2}{*}{ Variable } & \multicolumn{2}{|c|}{ Phenotype } & \multirow{2}{*}{$\mathrm{P}$} \\
\hline & Hair & Wool & \\
\hline \multicolumn{4}{|l|}{ Neck } \\
\hline $\mathrm{pH}$ & $6.1 \pm 0.06$ & $6.3 \pm 0.06$ & NS \\
\hline WHC & $50.7 \pm 3.82$ & $35.5 \pm 1.95$ & $* * *$ \\
\hline $\mathrm{Wa}$ & $0.97 \pm 0.00$ & $1.0 \pm 0.00$ & $*$ \\
\hline Raw meat thoughness $(\mathrm{N})$ & $3096.5 \pm 718.18$ & $2408.2 \pm 156.03$ & NS \\
\hline Cooked meat thoughness $(\mathrm{N})$ & $2468.2 \pm 312.19$ & $1697.4 \pm 60.13$ & $*$ \\
\hline \multicolumn{4}{|l|}{ Loin } \\
\hline $\mathrm{pH}$ & $5.8 \pm 0.07$ & $6.3 \pm 0.05$ & $* * *$ \\
\hline WHC & $42.4 \pm 2.37$ & $32.2 \pm 2.19$ & $*$ \\
\hline $\mathrm{Wa}$ & $0.9 \pm 0.01$ & $1.0 \pm 0.00$ & NS \\
\hline Raw meat toughness $(\mathrm{N})$ & $2737.2 \pm 191.08$ & $1208.9 \pm 92.46$ & $* * *$ \\
\hline Cooked meat toughness $(\mathrm{N})$ & $2034.0 \pm 241.43$ & $1285.2 \pm 60.15$ & $* * *$ \\
\hline
\end{tabular}

$* \mathrm{P} \leq 0.05 ; * * \mathrm{P} \leq 0.01 ; * * * \mathrm{P} \leq 0.001 ; \mathrm{NS} \mathrm{P}>0.05$.

WHC: water holding capacity; Wa: water activity.

Table 5. Effect of phenotype and body part in the color of lamb meat (mean \pm standard error)

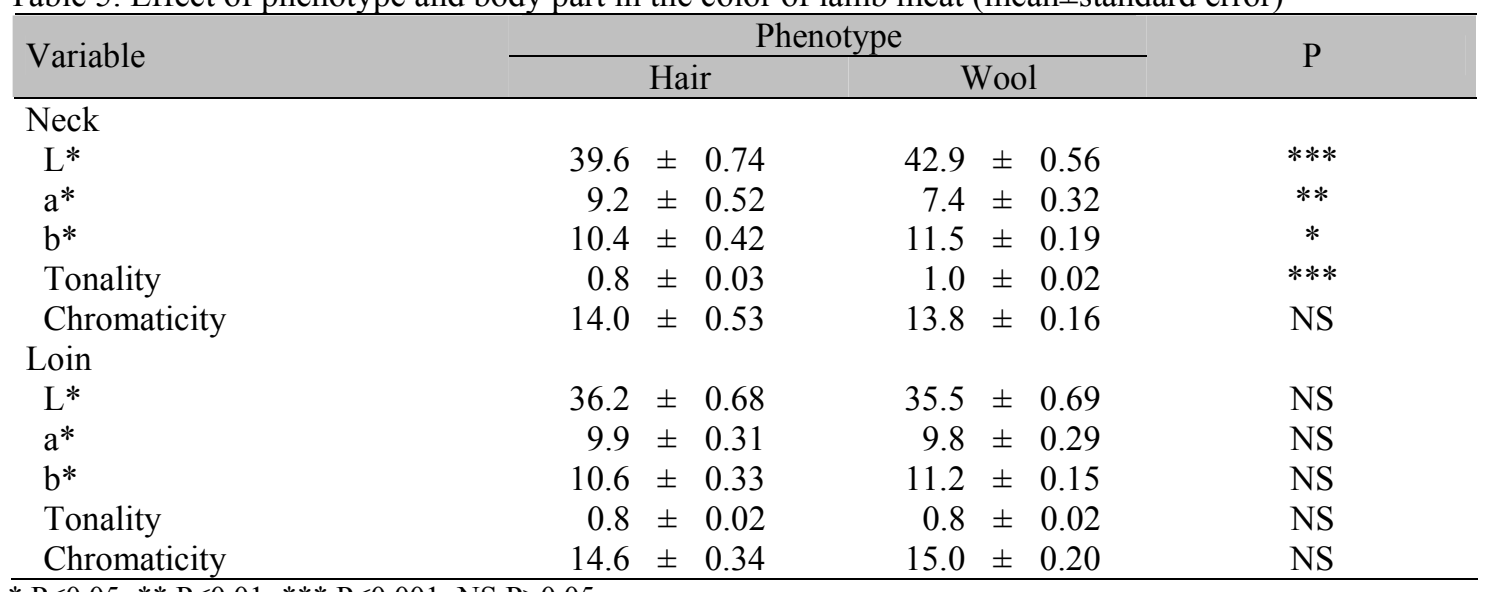

* $\mathrm{P} \leq 0.05 ; * * \mathrm{P} \leq 0.01 ; * * * \mathrm{P} \leq 0.001 ; \mathrm{NS} \mathrm{P}>0.05$.

$L^{*}$ : white (slight), $a^{*}$ : intensity of red, $b^{*}$ : intensity of yellow.

Chromaticity $\left.=\left(\mathrm{a}^{2}+\mathrm{b}^{2}\right)^{1 / 2}\right)$; tonality $=$ ang. $\tan ^{-1} \frac{b}{a}$.

Table 6 contains the results of the sensorial test. No significant differences were observed among the sensorial characteristics such as overall quality, flavor, odor, juiciness, and toughness (Table 6). These results do not support the general perspective of many consumers and processors that meat from hair lambs has sensorial characteristics (e.g. flavor) of lower value similar to goat meat. On the other hand, the meat cut up from the neck and loins have a very high demand here in Mexico. The loin has a higher economic value when it is solely marketed. However, the cuts in slices of neck and loin to roast have good acceptance in Mexican restaurants. The reason of choosing the neck cuts and loin in this investigation was in order to have pieces of low and high commercial value for other countries, but this difference is not very common in Mexico, because most of the meat is marketed as barbacoa. But in this way of selling the meat, the selection of the cuts loses the higher commercial value and all the pieces acquire the same price. 
Table 6. Effect of phenotype and body part on the meat quality of hair and wool lambs (mean \pm standard error)

\begin{tabular}{lcccc}
\hline \multirow{2}{*}{ Variable } & \multicolumn{3}{c}{ Phenotype } & \multirow{2}{*}{ P } \\
\cline { 2 - 3 } \multicolumn{1}{c}{ Hair } & $9.0 \pm 0.46$ & NS \\
Overall quality & $8.0 \pm 0.47$ & $8.6 \pm 0.54$ & NS \\
Flavor & $7.9 \pm 0.51$ & $8.7 \pm 0.44$ & NS \\
Odor & $8.5 \pm 0.47$ & $7.2 \pm 0.48$ & NS \\
Color & $7.7 \pm 0.32$ & $6.7 \pm 0.50$ & NS \\
Juiciness & $5.8 \pm 0.68$ & $5.1 \pm 0.64$ & NS \\
Hardness & $6.0 \pm 0.67$ & & \\
\hline
\end{tabular}

* $\mathrm{P} \leq 0.05 ; * * \mathrm{P} \leq 0.01 ; * * * \mathrm{P} \leq 0.001 ; \mathrm{NS} \mathrm{P}>0.05$.

\section{CONCLUSIONS}

Lamb phenotype influenced yield of carcass sides and back fat because of differences in the proportion of skin and viscera between hair and wool breeds, with wool lambs providing less yield. Phenotype also affected meat chemical composition and percent of palmitic acid, but not $\mathrm{pH}$. Hair lambs also had meat with a greater capacity for water retention and toughness. Meat from the neck of wool lambs was more luminous and less red than hair lambs. Based on these results, it is possible that similar feeding management for lambs from both phenotypes having similar age, weight, and gender, may produce meat with similar sensorial qualities. However, more research should be performed to include more breeds in different environments of Mexico.

\section{REFERENCES}

ALCALDE, J.M.; NEGUERUELA, A.I. The influence of final conditions on meat colour in light lamb carcasses. Meat Sci., v.57, p.117-123, 2001.

ARSENOS, G.; KUFIDIS, D.; ZYGOYIANNIS, D. et al. Fatty acid composition of lambs of indigenous dairy Greek breeds of sheep as affected by post-weaning nutritional management and weight at slaughter. Meat Sci., v.73, p.55-65, 2006.

BUNCH, T.D.; EVANS, R.C.; WANG, S. et al. Feed efficiency, growth rates, carcass evaluation, cholesterol level and sensory evaluation of lambs of various hair and wool sheep and their crosses. Small Rumin. Res., v.52, p.239-245, 2004.

BURKE, J.M.; APPLE, J.K.; ROBERTS, W.J. et al. Effect of breed-type on performance and carcass traits of intensively managed hair sheep. Meat Sci., v.63, p.309-315, 2003.

CAÑEQUE, V.; SAÑUDO C. Metodología para el estudio de la calidad de la canal y de la carne en rumiantes. Madrid: Instituto Nacional de Investigación y Tecnología Agraria y Alimentaría Ministerio de Ciencia y Tecnología, 2000. 255p.

CANTÓN， C.J.G.; VELÁZQUEZ， M.P.A. Productividad de corderos terminales de razas de pelo cruzadas de Suffolk. In: SARMIENTO, F.L.; RODRIGUEZ, R.O. (Eds). Producción de ovinos en el tropico. Merida, Mexico: INIFAPSARH, 1993. p.17-21.

CARBALLO, B.; LÓPEZ, T.G.; MADRID, A. Tecnología de la carne y de los productos carnicos. Madrid: Mundi-Prensa, 2001. 320p.

DÍAZ, M.T.; ÁLVAREZ, I.; DE LA FUENTE, J. et al. Fatty acid composition of meat from typical lamb production systems of Spain, United Kingdom, Germany and Uruguay. Meat Sci., v.71, p.256-263, 2005.

FELIX, U.L.; FELIX, U.D.; RUBIO, M.S. et al. Análisis comparativo de la carne y productos cárnicos de cabrito Alpino Francés y Alpino Francés (3/4) con Boer (1/4). Téc. Pec., v.39, p.237-244, 2001.

GUERRERO, L.I.; PONCE, A.E.; PÉREZ, M.L. Curso práctico de tecnología de cArnes y pescado. México, DF: Universidad Autónoma Metropolitana, Unidad Iztapalapa, 2002. 171p.

GUTIÉRREZ, J.; RUBIO, M.S.; MÉNDEZ, R.D. Effects of croossbreeding Mexican Pelibuey sheep with Rambouillet and Suffolk on carcass traits. Meat Sci., v.70, p.1-5, 2005. 
HERRERA, J.G; BARRERAS, A.S. Análisis estadístico de experimentos pecuarios. Mexico, DF: Colegio de Posgraduados, 2005. 215p.

HOFFMAN, L.C.; MULlER, M.; CLOETE, S.W.P. et al. Comparison of six crossbred types: sensory, physical and nutritional meat quality characteristics. Meat Sci., v.65, p.1265-1274, 2003.

HOPKINS, D.L; FOGARTY, N.M. Diverse lamb genotypes. 2. Meat, $\mathrm{pH}$, color and hardness. Meat Sci., v.49, p.477-488, 1998.

HUFF-LONERGAN, E.; LONERGAN S.M. Mechanisms of water-holding capacity of meat: the role of postmortem biochemical and structural changes. Meat Sci., v.71, p.194-204, 2005.

HUIDOBRO, F.R.; MIGUEL, E.; BLÁZQUEZ, B. et al. A comparison between two methods (Warner - Bratzler and texture profile analysis) for testing either raw meat or cooked meat. Meat Sci., v.69, p.527-536, 2005.

HUNT, M.C.; ACTON, J.C.; BENEDICT, R.C. et al. Guidelines for meat colour evaluation. Savoy: American Meat Science Association, 1991. p.3-17. (Publication, 44).

MARTÍNEZ-CEREZO, S.; SAÑUDO, C.; MEDEL, I. et al. Breed, slaughter weight and ageing time effects on sensory characteristics of lamb. Meat Sci., v.69, p.571-578, $2005 a$.

MARTÍNEZ-CEREZO, S.; SAÑUDO, C.; PANEA, B. et al. Breed, slaughter weight and ageing time effects on physico-chemical characteristics of lamb meat. Meat Sci., v.69, p.325-333, 2005b.

NORMA oficial mexicana NMX-FF-106-SCFI2006 aplicada a productos pecuarios - carne de ovino en canal. México, DF: SAGARPA, 2006.

OFFICIAL method of analysis of the AOAC. 17.ed. Gaisthersbug: AOAC, 2000.

RANKEN, M.D. Manual de la industria de la carne. Ediciones Mundi - Prensa. Madrid, España. 16 - 54 p, 2003.

SALVATORI, G.; PANTALEON, L.; DI CESARE, C. et al. Fatty acid composition and cholesterol content of muscles as related to genotype and vitamin $\mathrm{E}$ treatment in crossbred lambs. Meat Sci., v.67, p.45-55, 2004.

SAÑUDO, C.; ENSER, M.E.; CAMPO, M.M. et al. Fatty acid composition and sensory characteristics of lamb carcasses from Britain and Spain. Meat Sci., v.54, p.339-346, 2000.

SAÑUDO, C.; SANCHEZ A.; ALFONSO M. Small ruminant production systems and factors affecting lamb meat quality. Meat Sci., v.49, suppl.1, p.S29-S64, 1998.

TEXEIRA, A.; BATISTA, S.; DELFA, R. et al. Lamb meat quality of two breeds with protected origin designation. Influence of breed, sex and live weight. Meat Sci., v.71, p.530-536, 2005.

TSCHIRHART-HOELSCHER, T.E.; BAIRD, B.E.; KING, D.A. et al. Physical, chemical and histological characteristics of 18 lamb muscles. Meat Sci., v.73, p.48-54, 2006. 